\title{
Job losses loom in NASA restructuring plan
}

Washington. Scientists employed by the US National Aeronautics and Space Administration (NASA) would find themselves working for government-funded science 'institutes' under a restructuring plan unveiled by Daniel Goldin, NASA's administrator, last week.

The institutes, whose shape has been under review for several months (see Nature 374, 107; 1995), would be run by universities, consortia or private companies. Goldin says he does not expect the move to save money. But he says it will lead to "much stronger science for NASA" by leading to an increased use of peer review and greater cooperation with academic and industry scientists.

The proposed science institutes are only part of a wide-ranging restructuring of the agency that has been drawn up over the past year. Among other changes, the space shuttle would be turned over to a single contractor, with an eye to eventual privatization.

Overall, says Goldin, between 25,000 and 30,000 government and contractor employees will lose their jobs, although no centres will be closed and no major projects terminated. The scaling-back is the rcsult of reduced NASA budget projections published by the White House in January.

The science institutes would be carved out of existing programmes at the agency's 11 centres, and would use existing NASA facilities; Goldin has ruled out any new "brick and mortar". The Ames Research Center near San Francisco, for cxample, would house a new institute for astrobiology, and the Johnson Space Center near Houston will have institutes for biomedical and planetary science.

An atmospheric science institute will be set up at the Langley Research Center in Virginia, one devoted to microgravity and space power at the Lewis Research Center in Cleveland, and one for hydrology and other science at the Marshall Space Flight Center in Alabama.

The Goddard Space Flight Center in the Maryland suburbs of Washington DC will remain the agency's main centre for Earth science, physics and astronomy. The Jet Propulsion Laboratory in Pasadena, California will retain primary responsibility for Solar System exploration.

According to Goldin, planning is already under way for the first institute - the space biomedical research centre at Johnson and the head of a team bcing set up to oversee the transition from NASA's current biomedical science operations should be named by next week. Potential operators for the new institute include the Texas Medical Center.

Goldin said the agency will go slowly in setting up the institutes, using Goldin: promlses 'much Johnson as a pilot stronger science'. project. $\mathrm{He}$ and France Cordova, NASA's chief scientist, have been holding meetings with university deans, state governors and other officials, looking for potential institute sponsors. Cordova says she already has "a portfolio a couple of inches thick" of letters expressing interest in cooperating with NASA.

Even though many details still have to be worked out, Cordova hopes one or two institutes will be in place by 1997 . Last week she met science directors from the NASA centres to begin working out the details of how the institutes will be opened to competition for sponsors, how the contractual status of
NASA scientists will be organized, and other administrative matters.

Cordova says the institutes will involve a "more diverse, larger community" than NASA science laboratories do at present. "We're not trying to shape the institutes in NASA's image," she says.

In general, the idea of setting up privatized science institutes has been welcomed by the space science community. Anncila Sargent of the California Institute of Technology, who chairs NASA's science advisory committee, admits that some NASA science positions will be lost in the shuffle. But she says that considering the inevitability of cuts at the agency, "space science came out [of the restructuring] rather well".

Nevertheless, NASA's problems may be far from over. No sooner had Goldin announced the plan last week than he was fending off yet another attack on his budget from Congress. Further deep cuts proposed by the House of Representatives (see Nature, 375, 168; 1995) would have a "devas. tating effect on NASA centres and programmes", he warned, and would almost ccrtainly lead to the closure of centres and cancellation of projects.

One likely victim is the agency's Earth Observing System (EOS) satellite programme, which many Republicans see as little more than Vice President Al Gore's pet environmental project, and which has been drastically cut in the House budget plan.

An internal NASA memorandum being circulated in Washington last week speculated that, if the space agency had to meet the new House targets, "the common [EOS] spacecraft procurement could be slid to accommodate the funding profile," and the programme's sophisticated data distribution system "could be cancelled or completely restructured".

\section{NIH will reallocate research funding to support DNA sequencing}

Washington. Harold Varmus, the director of the US National Institutes of Health (NIH), said last week that he proposes to use the discretion he has been given by Congress in allocating a small amount of $\mathrm{NIH}$ funds to support new research initiatives in three areas; developing DNA sequencing technology, preparing a map of the rat genome and techniques for small-angle $\mathrm{X}$-ray scattering and spectroscopy.

Following the first meeting of a panel of experts he has set up to advise him on priorities in gene therapy research, Varmus said that, in the light of impending budget cuts under discussion in Congress, "we can't infuse huge sums of money into any new programme". But, he added, "I can move money around".

At the same meeting, Francis Collins, director of NIH's National Center for Human Genome Research, made a plea for the development of mechanisms for funding imaginative research on new potential vectors for gene therapy. "Perhaps we need to try some completely new virus, rather than taking small, incremental steps," he said. "There are too many reasons not to always take a safc approach."

The conclusions of the pancl, set up explicitly to assess NIH's investment in research in gene therapy, are expected to influence how Varmus allocates a discretionary fund amounting to 1 per cent of the total NIH budget that was authorized by Congress in its appropriations for the fiscal year 1995, which begins on 1 October. At present, NIH spends $\$ 135$ million a year on extramural research in gene therapy, and
\$61 million on its intramural programme.

The advisory panel, co-chaired by Stuart Orkin of Harvard Mcdical School in Boston and Arno Motulsky of the University of Washington in Seattle, heard about many promises, but few effective long-term therapies, in the quest to move gene therapy out of the laboratory and into the clinic. Several participants at last week's meeting said that current difficulties suggest more basic research may be needed before large-scale clinical trials are launched.

Their comments were prompted by the fact that, although many gene therapy protocols have yielded promising results in the carly stages, thesc are often overshadowed by lacklustre or inconsistent results in clinical trials.

According to Collins, one major hurdle to 